Timur Schukin

St. Pétersbourg

\title{
ICONOCLASTIC FRAGMENT OF THE APOLOGETIC NOTE BY JOHN ITALOS
}

If we try to define a theological issue in which pagan Neoplatonism and Byzantine Church Fathers are considered to differ unconditionally, irrespective of the degree of Platonic influence they experienced, it would be the issue of the relationship between an image and its prototype. Generally, we can formulate the pagan vision of this relationship as a particular intellectual nature's mimesis of the deity, which by itself is an intelligible nature. According to this position, the distinctive features of the image (e.g., each material component if we speak of a work of art) become temporal and accidental, and the subject of mimesis loses his entire content: the Intellect appears to be everywhere. ${ }^{1}$ This is why in the eleventh century, when the minds of Byzantine intellectuals once again became preoccupied with pagan concepts, the idea of this paradigm gained special significance. Its main trait was the relationship with the mind as a primeval divine substance. If Michael Psellos, when arguing with Maximus the Confessor and John Damascene, simply insisted that the mind was a special dominating substance and not merely part of the soul or its tool, though it is eternally present within the soul, ${ }^{2}$ John Italos taught that the human mind

(1) Cf. e. g. the saying of Plotinus that the soul even in its external appearances produces all its manifestations as through dispersed thoughts when imitating thinking and intellect. Referring to the prototype ( $\dot{\varrho} \chi \dot{\varepsilon} \tau \breve{\tau} \pi \mathrm{O})$ ), the

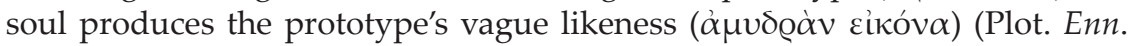
V.3.7, 25-34; cf. Plot. Enn. V.9.3, 33-37).

(2) According to Maximus the Confessor, the soul has two parts - rational and vital, and the rational one, in turn, is divided into active and contemplative. The contemplative part of the soul is the mind (Max. Myst. 5). John Damascene reproduces this teaching in his Expositio fidei (De fide orthodoxa 26 [II, 12], 48-49). He quotes Galenus' expression which he learned through Nemesius of Emessa (Nemes. nat. hom. I), that "like an eye in the body the mind is present in the soul." Disputing this, Psellos says that the mind "is not dynamis of the soul, it is rather a primary and eternal essence, surpassing the soul in power, in beauty and in all other order; it (the Nous) does not belong to the soul but rather fashions in after itself, it does not have its abode" (Mi- 
is already divine by its nature, ${ }^{3}$ being a participant in the hypostasis of the Intellect, similar to the participation of all individual beings in the hypostasis of the One, and of an individual soul - in the hypostasis of the Soul. ${ }^{4}$ Thus Italos following these apparently pagan views, was referring to the Neoplatonic doctrine of ascension from sensual things to the ideal, as he expounded his attitude toward material images.

Although among eleven anathemas of the Synodicon, ${ }^{5}$ there is no position which is related to the veneration of icons; the unorthodox character of philosopher John Italos' ideas concerning sacred icons was detected during his trial $-\mathrm{a}$ fact recorded in the materials of the case. ${ }^{6}$

The last point of the Note submitted by Italos for the consideration of the Emperor, contains some statements about icons. This Note is the most important document on this problem, firstly, because it is the

chaelis Pselli philosophica minora, vol. 2 (Leipzig, 1989) 95). George Karahalios pays special attention to this text and represents it in his brilliant dissertation (G. Karahalios, The Philosophical Trilogy of Michael Psellos: God-Kosmos-Man,

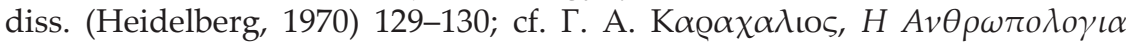

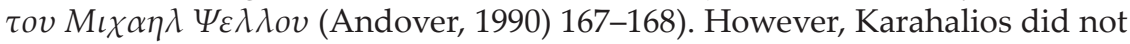
notice the polemical element of this saying - indirectly Psellos is disputing with Maximus the Confessor's anthropology and directly with Symeon the New Theologian's doctrine of partaking of the light (see e.g. Hymn. 1.29sqq; $12.8-14 ; 17.66-68 ; 18.120 ; 42.201)$. For the latter author the entire connection to Christ is important, which is contradicted by Psellos' doctrine of "anthropological emanation," when the light is received directly only by the mind, while the soul takes it only as a participant in the mind.

(3) See Н. Н. Кечакмадзе (ред.), Иоанн Итал, Сочинения (Тбилиси, 1966) 49.

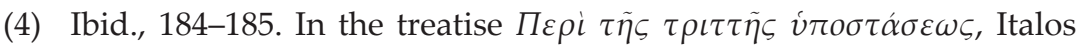

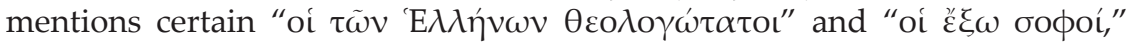
while not accepting and not rejecting their ideas. But in his next work T $\rho \varepsilon \tilde{\iota} \zeta$

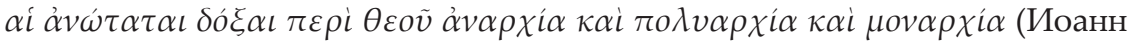
Итал, Сочинения, 185-188) he exposes the traditional doctrine of emanation as his own. For this reason we are inclined to think that he rather presents his own views than retells those of others in the treatise we referred to as well.

(5) J. Gouillard, Le Synodikon de l'Orthodoxie. Édition et commentaire, Travaux et mémoires 2 (1967) 56-61.

(6) J. Gouillard, Le Procès officiel de Jean l'Italien. Les actes et leurs sousentendus, Travaux et mémoires 9 (1985) 133-174; cf. S. SAlaville, Le procès de Jean Italos, EO 29 (1930) 141-146; L. CLucAs, The Trial of John Italos and the Crisis of Intellectual Values in Byzantium in the Eleventh Century (Munich, 1981) (Miscellanea Byzantina Monacensia 26). 
only source where we can find Italos' opinion about sacred icons - all other evidence is obscure. Secondly, even those writings that contain triadological and cosmological views of Italos, do not provide such an obvious form of his teaching, which helps us to understand the philosopher's attitude towards icons. As Kimon Giorkanis notes, "with men like Psellus and Italos it is also extremely difficult to determine whether they are merely giving an account of a philosophical position and defending it in terms of its own inner logic or whether they are asserting what they consider to be a philosophical truth." 7 This is why the text of the "Legal Proceedings" is indispensable. The situation compels John to speak for himself.

Here is the text of the Note:

From the last of [his] heretical chapters we learn thus: he said that he served the icon of the incarnated Son of God not remaining among



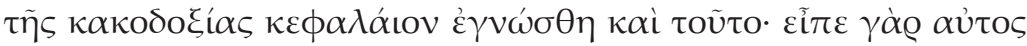

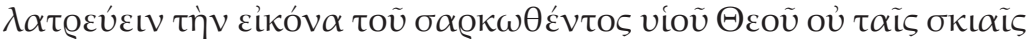

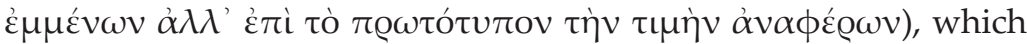
is clearly recognized as discordant with orthodox faith along with his other chapters. ${ }^{8}$

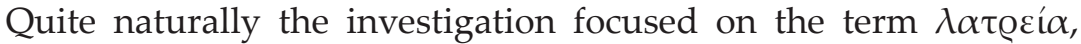
pointing out, first, that after the Seventh Ecumenical Council:

worship in the proper sense of the word is related to God's nature and we are called oì $\lambda \alpha \tau$ are to be relatively venerated because of the honour given to the prototype

secondly, referring to the authority of the Scripture and the Church Tradition:

(7) K. Giorkanis, Eustratius of Nicaea's defense of the doctrine of ideas, Franciscan Studies 24 (1964) 167.

(8) Gouillard, Le Procès..., 153. The term okı́x seems to have been borrowed by the Iconoclasts from Plato through Origen (V. A. BARANov, Origen and the Iconoclastic Controversy, in: L. Perrone et al (eds.), Origeniana Octava, Origen and the Alexandrian Tradition, vol. 2 (Leuven, 2003) (BETL 164) 1044). On the other hand, in the Platonist tradition the usage of $\varepsilon \dot{i k \omega} v$ in relation to a single thing, which goes back to the Timaeus, was commonplace; this also concerns the Alexandrian School which had an immediate influence upon Italos

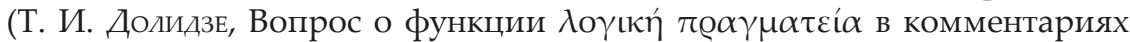
школы Аммония, Труды Тбилисского Университета 249 (1984) 330). Therefore it is difficult to resolve the question of terminological influences. 
the Scripture has never allowed anything of this kind,... we never confessed 'latria' as related to the sacred icons as well as we did not receive this from the canons of holy fathers, and moreover there is no such expression about the sacred icons in any place of the Synodicon.

Then the investigation reminds that:

There already occurred a great controversy about the sacred icons, and the admirers of them used to be slandered by the otherwiseminded as if they were icon-worshippers; when finally the honour of sacred icons prevailed with great difficulty according to God's Providence, and they were given reverence and admiration. ${ }^{9}$

All that was said is clear. In fact, Italos had no reason for using this term if he wanted to be in accord with tradition. However, the fact that Italos resorted to the patristic formula "from the image" (being understood one way or another) "to the prototype" (being understood one way or another), testifies that he did not want to conflict with the Church on this matter. On the other hand, Italos was certainly acquainted with Scripture; he actively quotes it in the letter to Emperor Michael Ducas ${ }^{10}$ and in other writings. Third, it is hard and even impossible to suppose that Italos did not know the theological debates of the previous epoch. ${ }^{11}$ And at last the main point - Italos did not challenge the authority of the Church, since he himself requested an investigation and submitted the Note with the exposition of his views to the trial.

Thus, if Italos did not reject what was condemned and at the same time completely recognized the authority of his judges, it means that he proceeded from other premises not only allowing the use of the word $\lambda \alpha \tau \varrho \varepsilon i ́ \alpha$ as applied to the deity but also to the image of God. Let us consider Italos' Note more closely.

(9) Gouillard, Le Procès..., 153.

(10) Иоанн Итал, Сочинения..., 129. It is necessary to mention that there are no more than ten such quotations in all of Italos' writings.

(11) We can firmly maintain that Italos was quite well acquainted with the works of John Damascene and thus he was aware of the Iconodules' position at the time of the first Iconoclasm. But in general, knowledge of the Iconoclast controversy in the eleventh century was rather vague (see B. LouriÉ, Une dispute sans justes: Léon de Chalcédoine, Eustrate de Nicée et la troisième querelle sur les images sacrées, SP 42 (2006) 321-340). 
First of all, it is necessary to identify the external sources of the text, because this may assist in examining Italos' thought due to the fact that he must have borrowed certain notions which fitted his reasoning. The fact that Italos modified the patristic formula "from a sensible image to the supersensible prototype" is notable because of the use of the rejected term $\lambda \alpha \tau \varrho \varepsilon i \alpha$. And the application of the patristic formula testifies to the fact that Italos did not reject patristic authority. Hence we can state that Italos neither neglects the tradition nor yet fully follows it. According to what was said above, the notion of $\lambda \alpha \tau$ té $\alpha$ is used by Italos exactly on the basis of the patristic doctrine that only the divine nature deserves "worship." Therefore Italos thought that he borrowed the term from tradition; and his use was not by accident, but deliberate. This word is indeed often used in Scripture. ${ }^{12}$ In Heb. 8:5, the apos-

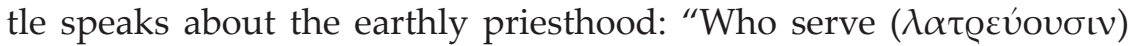

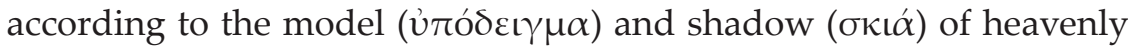
things." Italos certainly could rely on this text. From Heb. 10:1 it fol-

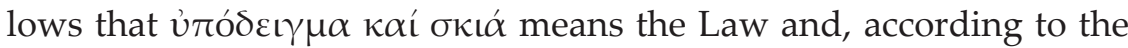
same Heb. 8:5, - the tabernacle of Moses. In Heb. 13:10 we find oi $\tau \tilde{\eta}$


of the true tabernacle - Christ, - and of his true servants, Christians. The apostle contrasts Christ to earthly priests yet he does not assert that this priesthood is no longer relevant. Thus the Scripture uses the verb $\lambda \alpha \tau \varrho \varepsilon v \omega$ in the context of the duality of "earthly service (the Law of the Old Testament)" and "Christian service," in other words, the

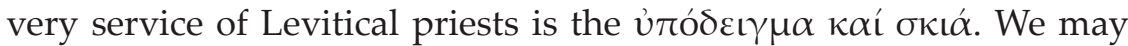
interpret this place in a negative sense for the Old Testament priests serving the Law, they serve it as something replacing God. Since "the service of the true tabernacle" is the service to Christ, in the figure of the New Testament priest the service of "the tabernacle according to the vision on Mount Sinai," that is the service of the image, and the true service coincide. And if the priest serves only the Law, that is "the earthly tabernacle," then his service is limited to the tabernacle and



In this case the word "service" could be used, first, in relation to God, ${ }^{13}$ and, second, when it is said of service as the image of true ser-

(12) E.g. Ex. 12:25,26; 1 Par. 28:13; Jo. 16:2; Rom. 9:4.

(13) See, for example, the words of Theodoret of Cyrrus who thus interprets Heb. 13:10: “One is much more honourable from ancient times, for the other one is the shadow. The other one is perceived as an irrational sacrifice, while the first one as rational and divine" (PG 82, 781C). 
vice, that is, of service not in its proper sense. ${ }^{14}$ Which of these meanings was closer to Italos? It seems to be the first one, because if he had used the term in the second meaning, there would have been no contradiction to tradition in his words, and Italos would not have been condemned.

Below in the text of the "Legal Proceedings" we may find the following words:

Being exposed as holding the views which he expounded contrary to the accuracy of the Church, John was brought to complete silence and confessed himself in front of everyone, and expressed full readiness to anathematize them ${ }^{15}$

Thus Italos listened to the arguments of the accusers. However, the arguments chiefly consisted of repeating the main definition of the Seventh Ecumenical Council - "service to God, veneration of God's icon," and referring to the Scripture, to patristic statements and to the text of the Synodicon, that is to the texts of which Italos could not be ignorant. It is possible to infer from this that Italos was persuaded not by these arguments; moreover, since Italos already knew the arguments of which the investigator reminded him, he changed his view not concerning how the term $\lambda \alpha \tau$ ¿í $\alpha$ should be used, but in his relation to the very subject of serving. Otherwise we cannot explain his change of mind.

Since we cannot explain Italos' deviation from Orthodoxy through inner Church tradition, which he accepted, consequently, rejecting what had been previously condemned by the Church, maybe we can detect in the Note something which might belong to the tradition not in its pure form but undergoing a certain transformation.

The Note uses the term okı $\alpha$, which means "a shadow, a phantom." It occurs in the Scripture in two places already mentioned (Heb. 8:5; Heb. 10:1), and in Col. 2:17. ${ }^{16}$ In all cases the stipulations of the old Law

(14) See the interpretation of Heb. 8:5 in John Chrysostom, Hom. 14 in Heb. 1-2; PG 63, 111-112; cf. John Damascene, De fide orthodoxa, 89. It is not by accident that Origen interprets this place distinctively in a negative way: The servants in the tabernacle served the image and shadow" (Or. fr. sel. in Ezech. 28; PG 13, 821B).

(15) Gouillard, Le Procès..., 155.



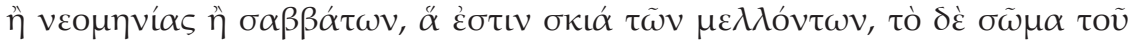

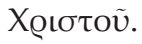


and the Law itself are named by this word. As was mentioned above, something is designated as okı́ as far as service rendered to it is concerned, but not relative veneration (and that the service to the shadow is cancelled in favour of true service). Italos certainly uses the term not because he thinks shadows deserve service; it comes from what was said above - Italos uses $\lambda \alpha \tau$ ¿cí $\alpha$ in its proper meaning. Therefore we may look for the doctrine that was behind Italos' assertions not in the patristic thought. It is also notable that in the Scripture okı $\alpha$ is used in the singular, while Italos uses the word in the plural. This is connected with the context of the word: the Scripture speaks of an uncountable and immaterial notion and Italos - of visible individual things. We may therefore seek for a text external to the Orthodox tradition where okı $x$ is used in the plural and in the sense of something, opposed to the thing whose "shadow" it is. This text immediately comes to mind: the symbol of the Cave from the seventh book of Plato's Republic.

It is important to briefly take into consideration the interpretation of the passage in the Platonic tradition. Proclus' voluminous treatise was the last Commentary on the Republic and it was closest to the time of Italos. It is of great interest to see in which sense the notion of okı $\alpha$ appears in the text. Yet first we should turn to the original text of Plato, because the text of the Note does not allow us to make any far reaching conclusions on which text Italos relied upon, on that of Plato or on Proclus' Commentary.

If we remember Plato's symbol of the Cave, first we hear the description of the fire up high, ${ }^{17}$ which is the metaphor of the Good, ${ }^{18}$ and the upper road, fenced by a low wall, above which some people carry various objects. Plato calls it the realm of the intelligible. ${ }^{19}$ Then the narrative turns to the Cave, where the prisoners are kept. They

resemble us ... for do you think ... the people see anything, be it their or other's, but the shadows ( $\tau \dot{\alpha} \varsigma$ okı $\alpha$ s) cast down by the fire onto the wall in front of them? ${ }^{20}$

Here Plato speaks about the realm of things pertaining to sensible vision. ${ }^{21}$ After that the following words express the ascension from the sensible to the intelligible, to the light of the Being:

(17) R.p., 514a, 1-515a, 3.

(18) Ibid., 517c, 1.

(19) Ibid., 517b, 5.

(20) Ibid., 515a, 5-8.

(21) Ibid., 517b, 2. 


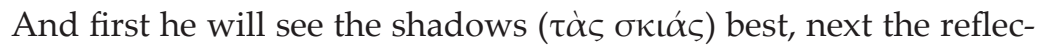
tions ( $\tau \dot{\alpha} \varepsilon \varepsilon^{\prime \prime} \delta \omega \lambda \alpha$ ) of men and other objects in the water, and then the objects themselves ( $\tau \dot{\alpha} \alpha \dot{v} \tau \dot{\alpha})^{22}$

By the "shadows" Plato means 1) the sensible, 2) the thing not in and of itself (this results from the former, because according to Plato the true Being is intelligible) $)^{23}$ and 3) something which is related to the preceding Being. The shadow is only linked to the ideal thing and is not anything substantial in and of itself as the very word connotes. We may briefly say that the shadow is the ideal reality manifested in a sensible and somewhat deceptive manner. ${ }^{24}$

In the form of an epistemological conclusion, it is clear that sensual perception according to Plato is a necessary point for ascension to the contemplation of the Being. Indeed the visible is the idea which is expressed by means of something other than itself. Therefore the ascension consists not of renouncing one thing in favour of another, but of sublimating the sensual that was introduced into the presence of the ideal. Thus all relations with sensual things are relations with the ideal, but the relation of such a kind that has to be overcome in so far as it is connected with the sensual presence.

And another important thing: Plato thinks that the first two beings are self-subsisting. ${ }^{25}$ The One could be identified with the Sun and the realm of the intelligible - with the objects in the opening of the Cave. It is also clear that the shadow is the idea manifested in another manner, for it already contains something of the ideal realm, but does not by itself belong there, because the shadow is the shadow of the thing and not of the Sun. Therefore it is an intellectual kind of relation that characterizes the connection between the thing and its shadow. Indeed the intellectual is able to put into being the other thing which is not self-subsisting. This not self-hypostatic other, which is the shadow, is nothing else but a particular or special eidos, which is manifested sensually. Thus the relation of the shadow is not the relation to the very

(22) R. p., 516a, 6-8.

(23) E. g.: Phaedr. 247de.

(24) Phaed. 83a, 3-5: “...It is known to those who aspire for knowledge... to what degree the eyesight is deceptive, and the hearing with the other senses are deceptive..."

(25) Tim., 30 b 6-c 1. 
idea but to a particular eidos, ${ }^{26}$ which by itself subsists in as much as it participates in the idea. Conversely, in as much as it is separated from the idea and set in the sensual, it lacks self-sufficient being.

Finally we should consider the definition of the term in Proclus' Commentary. ${ }^{27}$ Italos has a reference to the Commentary, although not very explicit: Proclus quotes and comments Homer, ${ }^{28}$ and Italos, when mentioning some "symbolic interpretations" of that very place in the "Iliad," 29 refers to Proclus. It can be affirmed that Italos might have been acquainted with this Commentary. ${ }^{30}$

If according to Plato every sensual thing is a step towards the contemplation of the Good-in-itself, Proclus says that there are things which man especially creates for this. Plato also had this thought, for example, implied in the words about the poet in the ideal state. ${ }^{31}$ The main thing is that Proclus made this thought explicit, and Italos seems to have borrowed it from him.

We should try to reconstruct the doctrine of Italos from his Note on

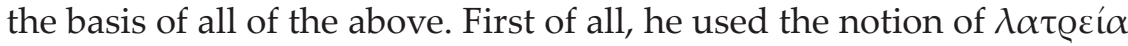
while realizing that only God has to be served and worshipped. Second, he admits the necessity of icons or otherwise he would look like

(26) As Italos apprehended Plato not directly but through the prism of the Platonist tradition of commentaries, I would "attribute" to Plato both three hypostases and particular eidoses, the developed doctrine of which appears only in Plotinus' "Enneads" as a content of the hypostasis of the Soul (see, for example, Plot. Enn. I.1.8). On the influence of pre-Proclusean Platonist tradition on the Byzantine thought of the 11th-12th centuries in this respect, see Giorkanis, Eustratius of Nicaea's defense...; G. Karahalios, The Philosophical Trilogy of Michael Psellos...

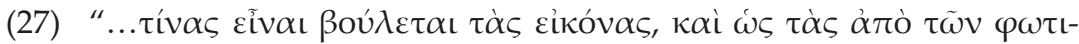

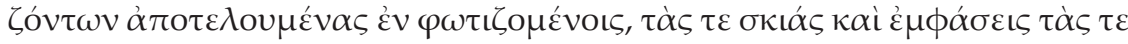

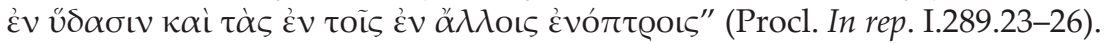

(28) Hom. Il. XXIV, 527.

(29) Иоанн Итал, Сочинения..., 193.

(30) How well the writings of Proclus were known in the 11th century is revealed by the fact that one of the few sources for the fragments of Proclus' commentary on Plotinus' Enneads became the work of Psellos, De Omnifaria Doctrina (L. G. Westerink, Exzerpte aus Proklos' Enneadenkommentar bei Psellus, BZ 52 (1959) 1).

(31) In Rep. 596 a5 - 598 d6 Plato says that the poet creates phantoms and in this he is likened to the painter. On the other hand, art is the imitation of the eidos. The poet can also produce a phantom which might serve for the strengthening of virtue and not for the wicked dispositions of the soul. 
an iconoclast. Italos calls the icon okıd , that is something deprived of self-subsistence. Therefore if one renders service to an icon, this happens not because it is a deity in and of itself, but precisely because it has no content of its own. On the other hand, however, the relation to the icon is a constant overstepping of its mere contemplation. Indeed if through an icon I appeal to God Himself, in the first moment of communication I have to remit the need of observing His shadow. To put it more strictly, the movement towards God is at the same time the complete renunciation of His likenesses. Thus the seeming contradiction between the need of rendering service to the icon and the renunciation of sensually perceived shadows is resolved by the fact that both actions are the same in nature. Furthermore, if both actions are necessarily linked, it is for no other reason than that they are predicated to the things of the same nature. And the nature, which gives substantial being to the other is the intellectual nature. This is the way John Italos comprehends the relationship between the image and the prototype as that of the intellectual nature to the form relevant to it (that is the ideal form).

The arguments of the investigators who refuted other positions of Italos' Note, namely those concerning the doctrine of deity, were more than a simple reference to authority, ${ }^{32}$ and perhaps this was the reason that made Italos change his mind about icons.

The views of Italos were typical for a Platonist, for whom the teaching on the contemplation of sensual things is the first degree of ascent to the Good. So we cannot insist on any distinct succession between Italos and the Iconoclasts of the 8th-9th centuries. More probably here

(32) The following charges were brought against Italos concerning his

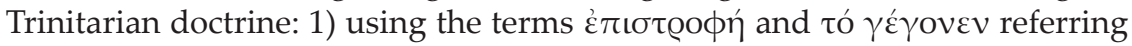
not to the hypostasis of the Son (as it was in Gregory of Nazianzus and Cyril of Alexandria: indeed "there was a time" when the Son of God was born according to his humanity), but to God's essence. The first term merges hypostases together, the second one identifies the birth of the Son before the ages and historical birth from the Virgin. The council identified these ideas as Arian; 2) application of expressions such as "one uncreated" or "one incomprehensible" without adding the name "God," that testified to Sabellianism, for the expression "one uncreated God" means the unity of the essence since the name "God" is also applied to the hypostasis, while the mentioned expressions point to abstract unity negating substantial threeness; 3 ) indivisibility of the Father, the Son and the Holy Spirit that is obvious Sabellianism (see Gouillard, Le Procès..., 145-149). 
we see the "iconoclast mode of thinking," for which the writings of great "external philosophers" gave an appropriate argumentation. ${ }^{33}$

\section{SUMMARY}

The ideological paradigm, a significant feature of which was a concept of mind as an originally divine substance, was formed in the 11th $\mathrm{C}$. The doctrine of the divine origin of the human mind may already be present in the works of Michael Psellos, but it is very clearly expressed in the works of his disciple John Italos. This article considers one of the consequences of the general anthropological framework - the teachings of the relationship between the image and the prototype. In 1082 during his trial on charges of heresy John Italos compiled a note with an outline of his theological views. One of the points of the note is related to the doctrine of icons. The philosopher, drawing on Neoplatonic epistemology going back to the "Cave metaphor" from Plato's Republic, relegates icons as sensual things to the lower epistemological level and calls them "shadows" ( $\sigma \kappa \iota \alpha i ́)$. On the other hand, since sensual things are the emanations of the divine mind, in the opinion of Italos icons just like God deserve "wor-

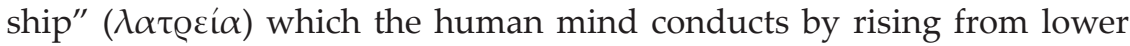
intellectual substances to the higher.

(33) The earlier and more expanded version of this paper was published in Russian as Т. Щукин, Иконоборчество Иоанна Итала, Проблемы теологии 3, вып. 2 (Екатеринбург, 2006) 77-98. 